\title{
Analisis Model Populasi Mangsa Pemangsa dengan Area Reservasi dan Pemanenan Pemangsa
}

\author{
Syamsul Agus ${ }^{1}$, Syamsuddin Toaha $^{2}$, Kasbawati $^{3}$
}

\begin{abstract}
Abstrak
Manajemen perikanan adalah upaya untuk mendukung konservasi sumber daya perikanan dan menghidari eksplotasi yang berlebihan serta tetap memberikan keuntungan ekonomi. Dalam tulisan ini dibahas suatu model populasi mangsa pemangsa dan pemanenan pada pemangsa dengan melibatkan fungsi biaya dan fungsi penerimaan. Dinamika ketiga spesies tersebut dimodelkan dengan mengasumsikan spesies mangsa di area bebas $(x)$, spesies di area reservasi $(y)$, dan spesies pemangsa di area bebas $(z)$ yang dinyatakan dalam bentuk sistem persamaan diferensial. Titik keseimbangan model beserta kestabilannya dianalisis dengan metode linearisasi dengan matriks Jacobi dan analisis kestabilan berdasarkan nilai eigen dari persamaan karakteristik dengan menggunakan kriteria Routh-Hurwitz, juga dianalisis dengan simulasi numerik untuk mengetahui kestabilan titik keseimbangan dan keuntungan maksimal. Hasil analisis menunjukkan bahwa kestabilan titik keseimbangan interior pada model ditentukan oleh nilai-nilai parameter model dan usaha pemanenan. Ketiga spesies tidak punah dan dapat tetap lestari meskipun ada usaha pemanenan serta dapat memberikan keuntungan maksimal
\end{abstract}

Kata kunci: Model Populasi Mangsa Pemangsa Perikanan, Titik Keseimbangan, Kestabilan, Pemanenan, Keuntungan Maksimal

\begin{abstract}
Fishery management is effort to support conservation of fishery resources and avoid excessive exploitation besides keep providing economic benefits. This paper discusses the model of prey predator population and harvesting on predators by involving the cost function and the reception function. The dynamics of the three species are modelled by assuming prey species in the free area $(x)$, species in the reservation area $(y)$, and predator species in the free area $(z)$ which is expressed in the system of differential equations. The equilibrium point of the model and its stability were analyzed by linearization method with a Jacobi matrix and stability analysis based on eigenvalues of characteristic equations using the criterion of Routh-Hurwitz. It is also analyzed by numerical simulation to know the stability of the balance point and maximum profit analysis. The result of analysis shows that the stability of the interior of equilibrium point on the model is determined by the value of the model parameters and harvesting effort. The three species are not extinct and able to sustain although there is a harvesting effort and provides maximum benefits.
\end{abstract}

Keywords: Model of Prey Predator Population in Fishery, Equilibrium Point, Stability, Harvesting, Maximum Profit.

${ }^{1}$ Universitas Hasanuddin

Email:acculagus@yahoo.com

${ }^{2}$ Universitas Hasanuddin

Email: syamsuddint@yahoo.com

${ }^{3}$ Universitas Hasanuddin

Email:kasbawati@gmail.com 


\section{Syamsul Agus, Syamsuddin Toaha, Kasbawati}

\section{Pendahuluan}

Sumber daya ikan merupakan sumber daya alam yang dapat pulih akan tetapi jika sumber daya alam tersebut akan terus tereksploitasi secara berlebihan (overfishing) yaitu tingkat upaya penangkapan ikan yang meningkat hingga mengganggu keseimbangan populasi ikan dan permasalahan kebijakan pemanenan yang tidak tepat yang berakibat tidak lagi diperoleh keuntungan dari pemanfaatan sumber daya perikanan tersebut bahkan bisa mengakibatkan kepunahan populasi ikan pada area tertentu di mana terjadi penangkapan ikan secara berlebihan tersebut. Selain itu kondisi lingkungan perairan yang merupakan habitat bagi ikan-ikan dan semua organisme yang ada di laut juga perlu diperhatikan. Kebijakan-kebijakan yang telah dibuat pemerintah untuk kegiatan penangkapan dan pengelolaan perikanan juga dapat membantu mengatur dan menjaga kelestarian sumber daya perikanan agar tetap dapat dimanfaatkan dan menghasilkan manfaat ekonomi.

Dalam suatu ekosistem setiap populasi selalu berinteraksi dengan populasi lainnya. Dalam interaksi tersebut terdapat rangkaian peristiwa yang dikenal dengan peristiwa mangsapemangsa. Salah satu contoh interaksi mangsa-pemangsa dalam perikanan adalah interaksi ikan tuna dan ikan kembung. Ikan tuna termasuk golongan ikan predator atau mencari makan dengan cara memburu mangsa dan biasanya menyerang mangsa secara bergerombol. Daerah perairan dengan kondisi area terumbu karang, serta perpindahan kedalaman dasar laut dari dangkal ke dalam atau sebaliknya merupakan habitat yang disukai ikan tuna, juga merupakan habitat alami berbagai jenis ikan-ikan kecil yang merupakan mangsa dari ikan tuna diantaranya ikan kembung.

Beberapa penelitian terdahulu yang mendasari penelitian ini, yaitu Zhang dkk.,(2007) mengkaji model mangsa pemangsa pada kegiatan penangkapan ikan di mana pemangsa diasumsikan selalu berada dan memangsa ikan di daerah bebas tangkap. Dubey (2007) juga mengkaji model mangsa-pemangsa pada area reservasi Kar dan Pahar (2007) mengkaji model mangsa-pemangsa dinamika sumber daya perikanan pada perairan suatu area. Chakraborty dkk., (2011) meneliti tentang model bifurkasi dan kontrol bioekonomi sistem mangsa pemangsa sumber daya perikanan dengan waktu tunda. Foley dkk., (2011) mengkaji model bioekonomi interaksi habitat ikan. Sedangkan Pratiwi (2013) mengkaji pengaruh waktu tunda pada pertumbuhan pemangsa dengan pemanenan pada populasi mangsa area bebas penangkapan ikan. Lv dkk., (2013) meneliti model mangsa-pemangsa dengan usaha penangkapan ikan pada sumber daya perikanan pada area tertentu dengan fungsi respon Holling type II dan Daga dkk., (2014) mengkaji tentang analisis stabilitas model mangsa pemangsa di area reservasi.

Berdasarkan penelitian-penelitian tersebut, akan dikaji suatu model populasi mangsa pemangsa dengan wilayah reservasi dan pemanenan pemangsa. Tujuan penelitian ini adalah menentukan model mangsa pemangsa, menentukan kestabilan titik keseimbangan, dan kebijakan pemanenan yang dapat memberikan keuntungan maksimum.

Tulisan ini merupakan merupakan pengembangan dari tulisan Dubey (2007) dan Foley dkk., (2011) dengan penambahan faktor pemanenan pada populasi pemangsa. 


\section{Bahan dan Metode}

Pada model ini terdapat tiga populasi spesies yang saling berinteraksi satu sama lain yakni populasi spesies mangsa di area bebas, populasi spesies di area reservasi dan populasi spesies pemangsa. Interaksi ketiganya dapat dilihat pada gambar 1.

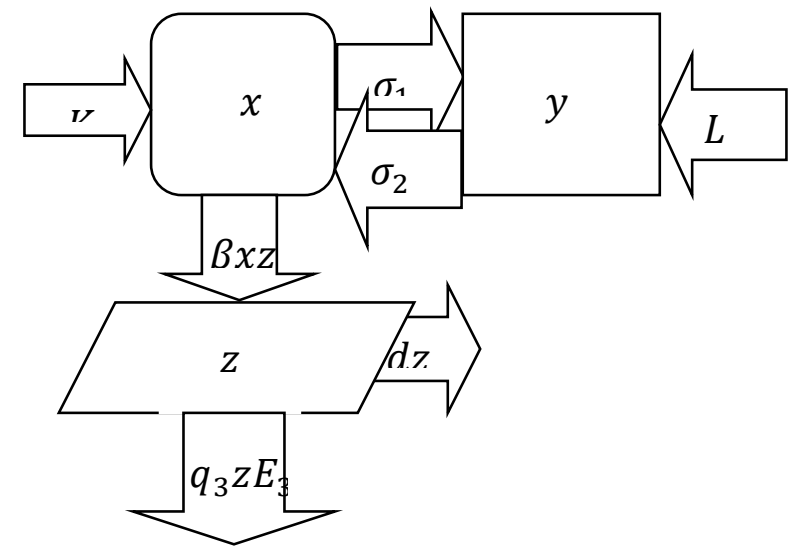

Gambar 1 Diagram Kompartemen Model Populasi Mangsa Pemangsa

Berdasarkan dari bagan di atas akan diperoleh model matematika mangsa pemangsa yang dapat dinyatakan sebagai berikut

$$
\begin{gathered}
\frac{d x}{d t}=r x\left(1-\frac{x}{g H+K}\right)-\sigma_{1} x+\sigma_{2} y-\alpha x z \\
\frac{d y}{d t}=s y\left(1-\frac{y}{L}\right)+\sigma_{1} x-\sigma_{2} y \\
\frac{d z}{d t}=\beta x z-e z-q_{3} z E_{3}
\end{gathered}
$$

Notasi $x(t)$ menyatakan kepadatan spesies mangsa di area bebas, $y(t)$ menyatakan kepadatan spesies mangsa di area reservasi dan $z(t)$ menyatakan kepadatan spesies pemangsa, $\sigma_{1}$ menyatakan angka perpindahan koefisien spesies mangsa dari area bebas ke area reservasi, $\sigma_{2}$ menyatakan angka perpindahan koefisien spesies dari area reservasi ke area bebas, $g H+K$ adalah modifikasi dari daya dukung lingkungan, $K$ adalah daya dukung lingkungan secara umum dan $g$ adalah koefisien sensitivitas dari habitat yang berpengaruh positif terhadap daya dukung lingkungan. Kelimpahan makanan pada habitat $(H)$ akan memperngaruhi pertumbuhan biomassa ikan.

Parameter $r, s, \alpha, \beta, e, q_{3}, E_{3}$ dan $L$ berturut-turut menyatakan koefisien laju pertumbuhan intinsik spesies mangsa pada area bebas, koefisien laju pertumbuhan intrinsik spesies mangsa pada area reservasi, angka penurunan spesies mangsa dengan adanya pemangsa, angka peningkatan spesies pemangsa akibat adanya pemangsaan, kematian alami pemangsa, koefisien ketertangkapan populasi pemangsa, usaha pemanenan pemangsa dan daya dukung lingkungan spesies mangsa di area reservasi. Secara umum penelitian yang dilakukan yaitu 
Syamsul Agus, Syamsuddin Toaha, Kasbawati

melinearisasi model, menentukan titik keeimbangan, menganalisis kestabilan titik keseimbangan, kemudian melakukan simulasi numerik. Adapun variabel penelitian adalah menganalisis kestabilan model populasi mangsa pemangsa dengan area reservasi dan pemanenan populasi pada pemangsa menggunakan metode linearisasi dan uji kestabilan Hurwitz.

\section{Hasil dan Pembahasan}

Dari model pada persamaan (1) diperoleh tiga titik keseimbangan yaitu

$$
\begin{gathered}
T_{1}=(0,0,0,), T_{2}=(\bar{x}, \bar{y}, 0,) \text {, dan } T_{3}=\left(x^{*}, y^{*}, z^{*}\right), \text { di mana } \\
x^{*}=\frac{e+q_{3} E_{3}}{\beta} \\
y^{*}=\frac{L\left(s-\sigma_{2}\right)}{2 s}+\frac{\left(\left(L\left(s-\sigma_{2}\right)\right)^{2}+4 s L \sigma_{1} x^{*}\right)^{\frac{1}{2}}}{2 s} \\
z^{*}=\frac{1}{\alpha(g H+K)}\left[\left(r-\sigma_{1}\right)(g H+K)-r x^{*}+\frac{\sigma_{2} y^{*}(g H+K)}{x^{*}}\right]
\end{gathered}
$$

Titik keseimbangan $T_{3}=\left(x^{*}, y^{*}, z^{*}\right)$ merupakan titik keseimbangan interior yaitu titik dengan $x^{*}>0, y^{*}>0, z^{*}>0$. Titik keseimbangan $T_{1}$ dan $T_{2}$ tidak dilakukan analisis kestabilan karena titik keseimbangan ini bukan merupakan titik keseimbangan interior. Analisis kestabilan hanya dilakukan pada titik keseimbangan interior yang merupakan syarat bahwa populasi tersebut ada. Hasil analisis kestabilan menggunakan metode linearisasi dan uji kestabilan Hurwitz menunjukkan bahwa titik keseimbangan $T_{3}$ merupakan titik keseimbangan yang stabil asimtotik

\section{a. Analisis Kestabilan Titik Keseimbangan}

Pada bagian ini akan dianalisis kestabilan titik keseimbangan dengan metode linearisasi. Misalkan persamaan (4.2) ditulis dalam bentuk

$$
\begin{gathered}
\dot{x}=r x\left(1-\frac{x}{g H+K}\right)-\sigma_{1} x+\sigma_{2} y-\alpha x z=f_{1} \\
\dot{y}=s y\left(1-\frac{y}{L}\right)+\sigma_{1} x-\sigma_{2} y=f_{2} \\
\dot{z}=\beta x z-e z-q_{3} z E_{3}=f_{3}
\end{gathered}
$$

Maka diperoleh matriks Jacobi dari persamaan (2)

$$
J=\left(\begin{array}{lll}
\frac{\partial f_{1}}{\partial x} & \frac{\partial f_{1}}{\partial y} & \frac{\partial f_{1}}{\partial z} \\
\frac{\partial f_{2}}{\partial x} & \frac{\partial f_{2}}{\partial y} & \frac{\partial f_{2}}{\partial z} \\
\frac{\partial f_{3}}{\partial x} & \frac{\partial f_{3}}{\partial y} & \frac{\partial f_{3}}{\partial z}
\end{array}\right)
$$




\section{Syamsul Agus, Syamsuddin Toaha, Kasbawati}

Dengan mensubsitusi titik keseimbangan $T_{3}=\left(x^{*}, y^{*}, z^{*}\right)$ pada matriks Jacobi $J$ diperoleh

$J^{*}=\left(\begin{array}{ccc}r-\frac{2 r x^{*}}{g H+K}-\sigma_{1}-\alpha z^{*} & \sigma_{2} & -\alpha x^{*} \\ \sigma_{1} & s-\sigma_{2}-\frac{2 s y^{*}}{L} & 0 \\ \beta z^{*} & 0 & \beta x^{*}-e-q_{3} E_{3}\end{array}\right)$

persamaan karakteristik dari matriks Jacobi $J^{*}$ adalah $\left|J^{*}-\lambda I\right|=0$. Dalam bentuk yang lebih sederhana diperoleh

dengan

$$
\lambda^{3}+p_{2} \lambda^{2}+p_{1} \lambda+p_{0}
$$

$$
\begin{aligned}
& p_{0}=-\left(r-\frac{2 r x^{*}}{g H+K}-\sigma_{1}-\alpha z^{*}\right)\left(s-\sigma_{2}-\frac{2 s y^{*}}{L}\right)\left(\beta x^{*}-e-q_{3} E_{3}\right) \\
& p_{1}=\left(r-\frac{2 r x^{*}}{g H+K}-\sigma_{1}-\alpha z^{*}\right)\left(s-\sigma_{2}-\frac{2 s y^{*}}{L}\right)+ \\
& \left(r-\frac{2 r x^{*}}{g H+K}-\sigma_{1}-\alpha z^{*}\right)\left(\beta x^{*}-e-q_{3} E_{3}\right)+ \\
& \quad\left(\beta x^{*}-e-q_{3} E_{3}\right)\left(s-\sigma_{2}-\frac{2 s y^{*}}{L}\right) \\
& p_{2}=-\left[\left(r-\frac{2 r x^{*}}{g H+K}-\sigma_{1}-\alpha z^{*}\right)+\left(s-\sigma_{2}-\frac{2 s y^{*}}{L}\right)+\left(\beta x^{*}-e-q_{3} E_{3}\right)\right] .
\end{aligned}
$$

Selanjutnya dilakukan uji kestabilan Hurwitz. Titik keseimbangan $T_{3}=\left(x^{*}, y^{*}, z^{*}\right)$ stabil asimptotik jika memenuhi

$p_{0}, p_{1}, p_{2}>0$, dan $p_{2} p_{1}-p_{0}>0$

sifat kestabilan $T_{3}=\left(x^{*}, y^{*}, z^{*}\right)$ akan ditunjukkan dengan simulasi numerik.

b. Keuntungan Maksimal Pemanenan Titik Keseimbangan Interior

Titik keseimbangan interior $T_{3}=\left(x^{*}, y^{*}, z^{*}\right)$ merupakan titik keseimbangan yang stabil asimptotik serta kaitannya dengan keuntungan maksimal $(\pi)$, masalah penerimaan total $(T R)$, masalah biaya total $(T C)$, serta masalah usaha pemanenan $E_{3}$. Dalam hal ini fungsi produksi adalah hubungan antara usaha (effort) dan hasil, sedangkan fungsi keuntungan dinyatakan dengan $\pi=T R-T C$

di mana

$$
\begin{gathered}
T C=c_{3} E_{3} \\
T R=q_{3} p_{3} E_{3} Z .
\end{gathered}
$$

Dalam hal ini harga per unik tangkapan untuk stok populasi spesies $x$ dan populasi spesies $z$ dinyatakan sebagai $p_{3}$. Biaya total dengan $c_{3}$ merupakan unit biaya pemanenan 
Syamsul Agus, Syamsuddin Toaha, Kasbawati

diasumsikan proporsional hasil tangkapan dengan usaha pemanenan $E_{3}$ dengan koefisien ketertangkapan populasi spesies pemangsa dinyatakan dengan $q_{3}$.

Dengan demikian penerimaan total dinyatakan sebagai fungsi terhadap $E_{3}$. Keuntungan maksimal penerimaan pada titik keseimbangan interior $T_{3}$ dapat dinyatakan dengan

$$
\pi=T R-T C
$$

$$
\begin{aligned}
& \pi=E_{3}\left(q_{3} p_{3} z^{*}-c_{3}\right) \\
& \pi=\frac{E_{3} q_{3} p_{3}\left(r-\sigma_{1}\right)}{\alpha}-\frac{E_{3} q_{3} p_{3} r x^{*}}{\alpha(g H+K)}+\frac{E_{3} q_{3} p_{3} \sigma_{2}(g H+K) y^{*}}{\alpha x^{*}(g H+K)}-E_{3} c_{3}
\end{aligned}
$$

Karena titik keseimbangan $T_{3}=\left(x^{*}, y^{*}, z^{*}\right)$ bergantung pada usaha pemanenan yang dilakukan maka fungsi keuntungan akan bergantung pada usaha pemanenan. Untuk itu menentukan nilai usaha pemanenan yang merupakan keuntungan maksimal maka titik kritis usaha pemanenan pada fungsi keuntungan perlu ditentukan, terlebih dahulu ditentukan titik stationer dari fungsi keuntungan tersebut.

Dari persamaan (5) maka diperoleh

$$
\begin{aligned}
\frac{\partial \pi}{\partial E_{3}}= & \frac{q_{3} p_{3}\left(r-\sigma_{1}\right)}{\alpha}-\frac{q_{3} p_{3} r\left(E_{3} q_{3}+e\right)}{\beta \alpha(g H+K)}-\frac{E_{3} q_{3}{ }^{2} p_{3} r}{\beta \alpha(g H+K)} \\
& +\frac{\left[q_{3} p_{3} \sigma_{2}\left(L \beta s-L \beta \sigma_{2}+\sqrt{L^{2} \beta^{2} s^{2}-2 L^{2} \beta^{2} s \sigma_{2}+L^{2} \beta^{2}{\sigma_{2}}^{2}+4 L \beta s E_{3} q_{3} \sigma_{1}+4 L e \beta s \sigma_{1}}\right)\right]}{2 s \alpha\left(E_{3} q_{3}+e\right)} \\
& +\frac{E_{3} q_{3}{ }^{2} p_{3} \sigma_{2} L \beta \sigma_{1}}{\alpha\left(E_{3} q_{3}+e\right) \sqrt{L^{2} \beta^{2} s^{2}-2 L^{2} \beta^{2} s \sigma_{2}+L^{2} \beta^{2} \sigma_{2}{ }^{2}+4 L \beta s E_{3} q_{3} \sigma_{1}+4 L d \beta s \sigma_{1}}} \\
& -\frac{\left[E _ { 3 } q _ { 3 } { } ^ { 2 } p _ { 3 } \sigma _ { 2 } \left(L \beta s-L \beta \sigma_{2}+\sqrt{\left.L^{2} \beta^{2} s^{2}-2 L^{2} \beta^{2} s \sigma_{2}+L^{2} \beta^{2}{\sigma_{2}}^{2}+4 L \beta s E_{3} q_{3} \sigma_{1}+4 L e \beta s \sigma_{1}\right)}\right.\right.}{2 s \alpha\left(E_{3} q_{3}+e\right)^{2}}-c_{3}
\end{aligned}
$$

Keuntungan maksimal diperoleh dengan turunan kedua dari persamaan (5) yakni

$$
\begin{aligned}
\frac{\partial^{2} \pi}{\partial^{2} E_{3}}= & -\frac{2 p_{3} q_{3}{ }^{2} r}{\beta \alpha(g H+K)} \\
& +\frac{2 q_{3}{ }^{2} p_{3} \sigma_{2} L \beta \sigma_{1}}{\alpha\left(E_{3} q_{3}+e\right) \sqrt{L^{2} \beta^{2} s^{2}-2 L^{2} \beta^{2} s \sigma_{2}+L^{2} \beta^{2} \sigma_{2}^{2}+4 L \beta s E_{3} q_{3} \sigma_{1}+4 L e \beta s \sigma_{1}}} \\
& -\frac{\left[q_{3}{ }^{2} p_{3} \sigma_{2}\left(L \beta s-L \beta \sigma_{2}+\sqrt{L^{2} \beta^{2} s^{2}-2 L^{2} \beta^{2} s \sigma_{2}+L^{2} \beta^{2} \sigma_{2}{ }^{2}+4 L \beta s E_{3} q_{3} \sigma_{1}+4 L e \beta s \sigma_{1}}\right)\right]}{s \alpha\left(E_{3} q_{3}+e\right)^{2}} \\
& -\frac{2 E_{3} q_{3}{ }^{3} p_{3} \sigma_{2} L^{2} \beta^{2} \sigma_{1}{ }^{2} s}{\alpha\left(E_{3} q_{3}+e\right) \sqrt{\left(L^{2} \beta^{2} s^{2}-2 L^{2} \beta^{2} s \sigma_{2}+L^{2} \beta^{2} \sigma_{2}{ }^{2}+4 L \beta s E_{3} q_{3} \sigma_{1}+4 L e \beta s \sigma_{1}\right)^{3}}} \\
& -\frac{2 E_{3} q_{3}{ }^{3} p_{3} \sigma_{2} L \beta \sigma_{1}}{\alpha\left(E_{3} q_{3}+e\right)^{2} \sqrt{L^{2} \beta^{2} s^{2}-2 L^{2} \beta^{2} s \sigma_{2}+L^{2} \beta^{2} \sigma_{2}{ }^{2}+4 L \beta s E_{3} q_{3} \sigma_{1}+4 L e \beta s \sigma_{1}}}
\end{aligned}
$$




$$
+\frac{\left[E_{3} q_{3}{ }^{3} p_{3} \sigma_{2}\left(L \beta s-L \beta \sigma_{2}+\sqrt{L^{2} \beta^{2} s^{2}-2 L^{2} \beta^{2} s \sigma_{2}+L^{2} \beta^{2} \sigma_{2}{ }^{2}+4 L \beta s E_{3} q_{3} \sigma_{1}+4 L e \beta s \sigma_{1}}\right)\right]}{s \alpha\left(E_{3} q_{3}+e\right)^{3}}
$$

Selanjutnya dilakukan uji numerik untuk mengetahui nilai maksimun yaitu apabila $\frac{\partial^{2} \pi}{\partial^{2} E_{3}}<0$. Dari persamaan (6) didapat titik kritis masing-masing dari persamaan adalah

$$
\begin{aligned}
& \frac{\partial \pi}{\partial E_{3}}=0 \\
& \frac{\partial \pi}{\partial E_{3}}= \frac{q_{3} p_{3}\left(r-\sigma_{1}\right)}{\alpha}-\frac{q_{3} p_{3} r\left(E_{3} q_{3}+e\right)}{\beta \alpha(g H+K)}-\frac{E_{3} q_{3}{ }^{2} p_{3} r}{\beta \alpha(g H+K)} \\
&+\frac{\left[q_{3} p_{3} \sigma_{2}\left(L \beta s-L \beta \sigma_{2}+\sqrt{L^{2} \beta^{2} s^{2}-2 L^{2} \beta^{2} s \sigma_{2}+L^{2} \beta^{2} \sigma_{2}{ }^{2}+4 L \beta s E_{3} q_{3} \sigma_{1}+4 L e \beta s \sigma_{1}}\right)\right]}{2 s \alpha\left(E_{3} q_{3}+e\right)} \\
& {\left[q_{3} p_{3} \sigma_{2}\left(L \beta s-L \beta \sigma_{2}+\sqrt{\left.L^{2} \beta^{2} s^{2}-2 L^{2} \beta^{2} s \sigma_{2}+L^{2} \beta^{2} \sigma_{2}{ }^{2}+4 L \beta s E_{3} q_{3} \sigma_{1}+4 L e \beta s \sigma_{1}\right)}\right]\right.} \\
&+\frac{E_{3} q_{3}{ }^{2} p_{3} \sigma_{2} L \beta \sigma_{1}}{\alpha\left(E_{3} q_{3}+e\right) \sqrt{L^{2} \beta^{2} s^{2}-2 L^{2} \beta^{2} s \sigma_{2}+L^{2} \beta^{2} \sigma_{2}{ }^{2}+4 L \beta s E_{3} q_{3} \sigma_{1}+4 L e \beta s \sigma_{1}}} \\
&-\frac{\left[E _ { 3 } q _ { 3 } { } ^ { 2 } p _ { 3 } \sigma _ { 2 } \left(L \beta s-L \beta \sigma_{2}+\sqrt{L^{2} \beta^{2} s^{2}-2 L^{2} \beta^{2} s \sigma_{2}+L^{2} \beta^{2} \sigma_{2}{ }^{2}+4 L \beta s E_{3} q_{3} \sigma_{1}+4 L e \beta s c}\right.\right.}{2 s \alpha\left(E_{3} q_{3}+e\right)^{2}} \\
&-c_{3}=0 .
\end{aligned}
$$

Dari persamaan di atas didapat $E_{3}{ }^{*}$. Adapun $E_{3}{ }^{*}$ akan di cari yang menghasilkan keuntungan maksimal, yang selanjutnya akan dilakukan uji simulasi numerik.

c. Simulasi Numerik Penentuan Titik Keseimbangan, Kestabilan dan Keuntungan Maksimal.

Pada bagian ini membahas tentang simulasi model mangsa pemangsa perikanan dengan wilayah reservasi dan pemanenan pemangsa. Nilai parameter yang digunakan untuk simulasi dalam tesis mempertimbangkan nilai parameter beberapa penelitian lain yang relevan.

Tabel 4.2. Keterangan Variabel dan Parameter Model dalam Persamaan (1),

\begin{tabular}{ccc}
\hline Parameter & Nilai & Sumber \\
\hline$\sigma_{1}$ & 0,2 & Kar dan Pahar (2007) \\
$\sigma_{2}$ & 0,2 & Kar dan Pahar $(2007)$ \\
$r$ & 0,75 & asumsi \\
$s$ & 0,4 & asumsi \\
$\beta$ & 0,01 & asumsi \\
$g$ & 0,1 & asumsi \\
$e$ & 0,6 & asumsi \\
$\alpha$ & 0,05 & asumsi \\
$K$ & 150 & asumsi \\
$L$ & 150 & asumsi \\
$H$ & 30 & asumsi \\
$p_{3}$ & 15 & Chakraborty dkk (2011) \\
$c_{3}$ & 0,5 & Chakraborty dkk (2011) \\
$q_{3}$ & 0,8 & asumsi \\
\hline
\end{tabular}


Hasil dari nilai simulasi numerik diperoleh titik keseimbangan dengan

$T_{1}=(0,0,0), T_{2}=(152,5453035,150,8452591,0)$ dan $T_{3}=\left(x^{*}, y^{*}, z^{*}\right)$, di mana

$x^{*}=80 E_{3}+60, y^{*}=37,5+2,5 \sqrt{945+960 E_{3}}$

$z^{*}=5,117647057-7,843137252 E_{3}+\frac{3.999999999\left(37,5+2,5 \sqrt{945+960 E_{3}}\right)}{80 E_{3}+60}$.

Dari persamaan (8) dengan nilai parameter di atas didapat

$E_{3}{ }^{*}{ }_{1}=0,5537302600,{E_{3}}^{*}{ }_{2}=-0,8188219282+0,3414601314 I$

$E_{3}{ }^{*}=-0,8188219282-0,3414601314 I$

Nilai usaha pemanenan $\left(E_{3}{ }^{*}\right)$ dengan syarat $0 \leq E_{3}{ }^{*} \leq 1$, sehingga nilai titik kritis $E_{3}{ }^{*}$ yang mungkin adalah $E_{3}{ }^{*}=0,5537302600$.

Selanjutnya uji numerik turunan kedua dari fungsi keuntungan diperoleh

$\frac{\partial^{2} \pi}{\partial^{2} E_{3}}=-233,6633874<0$

Karena $\frac{\partial^{2} \pi}{\partial^{2} E_{3}}<0$ sehingga keuntungan maksimal yaitu

$$
\pi\left(E_{3}{ }^{*}\right)=E_{3}{ }^{*}\left(q_{3} p_{3} z^{*}-c_{3}\right)
$$

$\pi\left(E_{3}{ }^{*}\right)=38,90804054$.

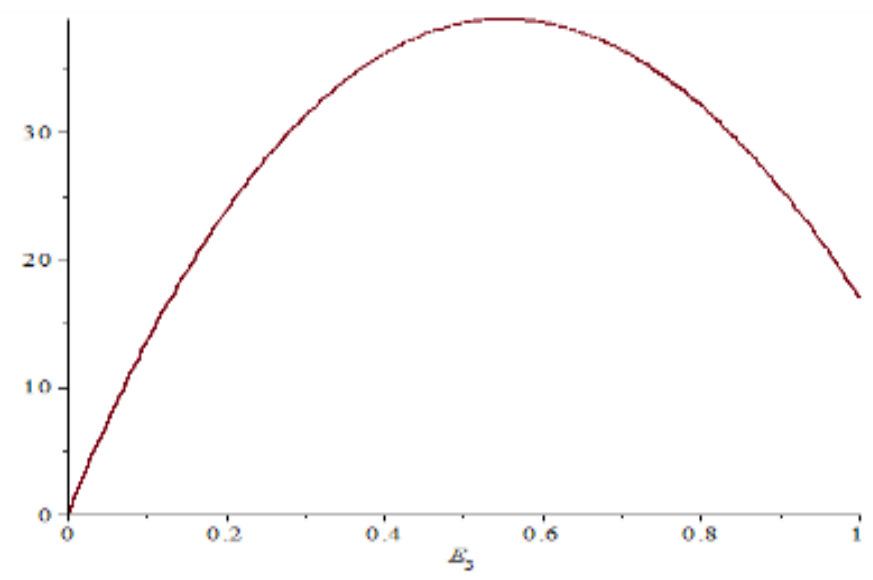

Gambar 4.2 Kurva Fungsi Keuntungan

Dengan mensubtitusi nilai $E_{3}{ }^{*}=0,5537302600$ diperoleh titik keseimbangan $T_{3}=(104,2984208,133,5657668,5,897110997)$.

Persamaan karakteristik didapat dari simulasi numerik yakni 


$$
\lambda^{3}+1,279739843 \lambda^{2}+0,6607020615 \lambda+0,1575630653=0
$$

Serta juga diperoleh nilai eigen dari persamaan karakteristik (3)

$$
\begin{aligned}
& \lambda_{1}=-0,326553193669781+0,380534834892163 I \\
& \lambda_{2}=-0,326553193669781-0,380534834892163 I \\
& \lambda_{3}=-0,626633455960438 .
\end{aligned}
$$

Dari hasil simulasi tersebut memperlihatkan bagian real nilai eigen yang diperoleh semuanya bernilai negatif $\left(\lambda_{1}, \lambda_{2}, \lambda_{3}<0\right)$, berdasarkan teoremai 2.3 dapat disimpulkan bahwa titik keseimbangan $T_{3}=\left(x^{*}, y^{*}, z^{*}\right)$ merupakan titik interior yang stabil asimptotik. Tahapan berikutnya dilakukan analisis kestabilan titik keseimbangan dengan uji kestabilan Hurwitz dan diperoleh

$$
\begin{aligned}
& p_{0}=0,1575630653, p_{1}=0,6607020615, p_{2}=1,279739843 \\
& p_{2} p_{1}-p_{0}=(1,279739843)(0,6607020615)-(0,1575630653) \\
& p_{2} p_{1}-p_{0}=0,6879636872>0 .
\end{aligned}
$$

Oleh karna $p_{0}>0, p_{1}>0, p_{2}>0$, dan $p_{0} p_{1}-p_{2}>0$, maka menurut uji kestabilan Hurwitz titik keseimbangan $T_{3}=\left(x^{*}, y^{*}, z^{*}\right)$ merupakan titik keseimbangan stabil asimptotik.

Selanjutnya dengan mengambil nilai awal di sekitar titik keseimbangan $T_{3}$ yaitu $x(0)=100, y(0)=130, z(0)=5$ diperoleh kurva sebagai berikut:

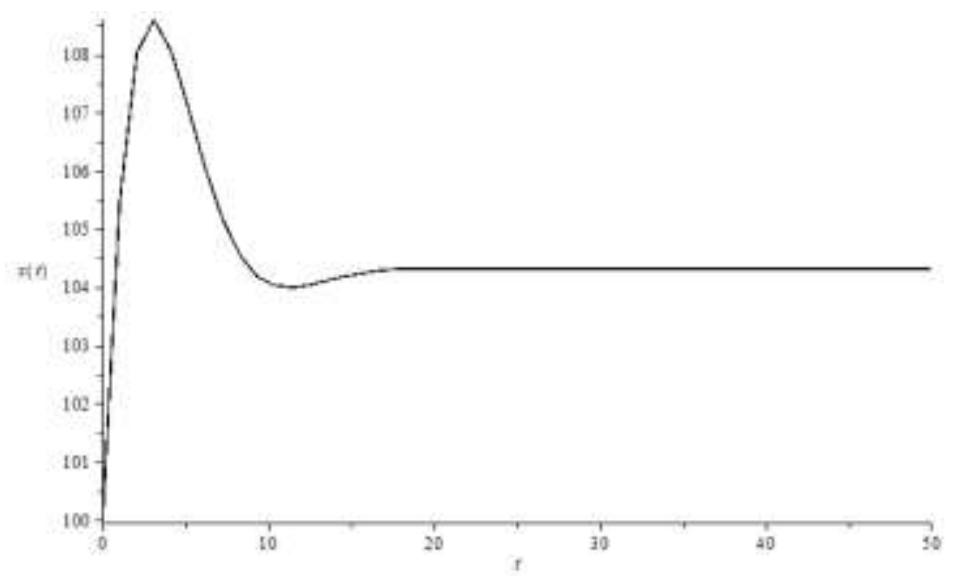

Gambar 4.3 Kurva Spesies Mangsa pada Area Bebas $(x)$ 
Syamsul Agus, Syamsuddin Toaha, Kasbawati

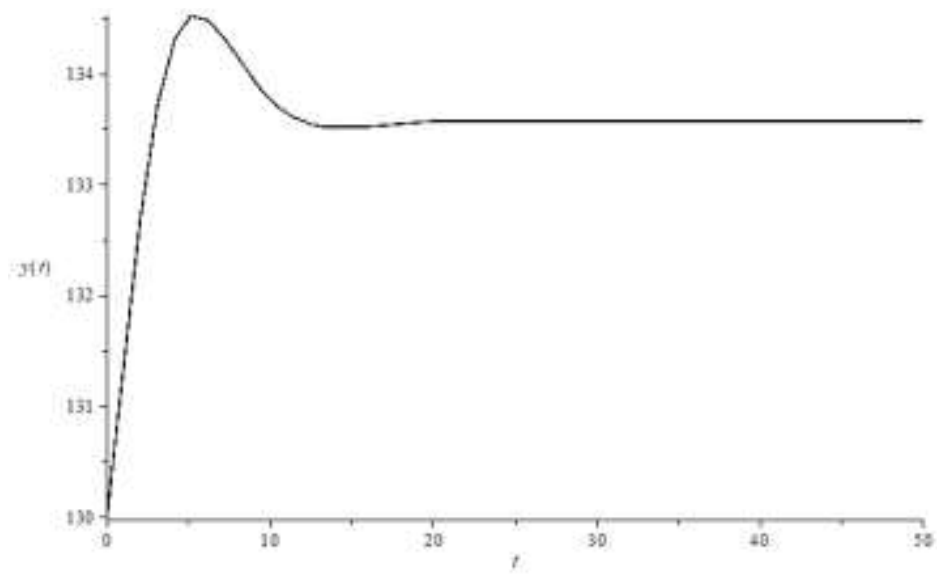

Gambar 4.4 Kurva Spesies pada Area Reservasi $(y)$

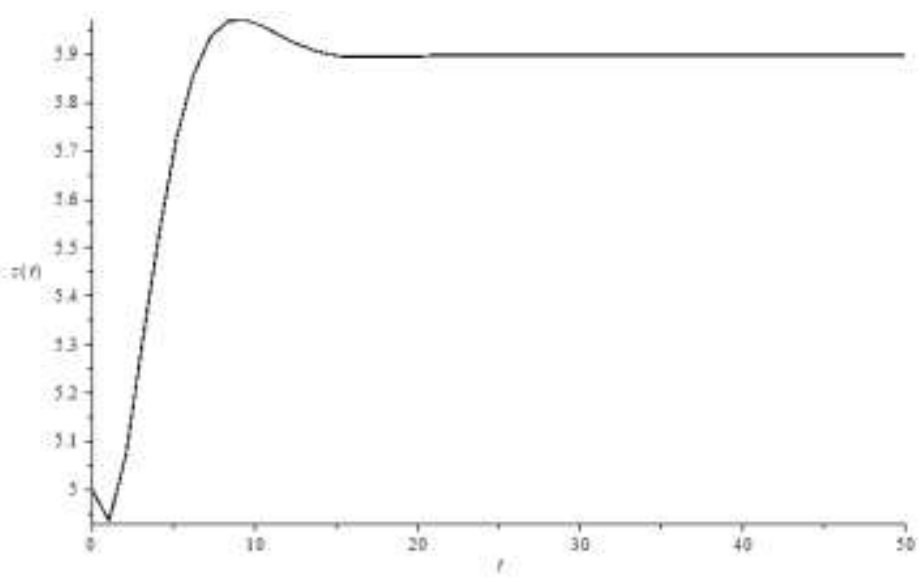

Gambar 4.5 Kurva Spesies Pemangsa pada Area Bebas (z)

Dari gambar (4.3), (4.4), dan (4.5) terlihat bahwa spesies mangsa dan pemangsa tidak alan punah seiring berjalannya waktu dengan nilai usaha pemanenan $E_{3}{ }^{*}=0,5537302600$ pada pemangsa .Dengan demikian pemangsa yang dieksplotasi dengan usaha pemanenan konstan tetap lestari untuk waktu yang lama serta memberikan keuntungan maksimal dengan sebesar $\pi\left(E_{3}{ }^{*}\right)=$ 38,90804054 .

\section{Kesimpulan}

Dari penelitian yang dilakukan mengenai analisis model populasi mangsa pemangsa dengan wilayah reservasi dan pemanenan pemangsa diperoleh kesimpulan sebagai berikut:

1. Model sistem dinamika populasi mangsa pemangsa sumber daya perikanan dengan wilayah reservasi serta pemanenan pada populasi pemangsa adalah:

$$
\frac{d x}{d t}=r x\left(1-\frac{x}{g H+K}\right)-\sigma_{1} x+\sigma_{2} y-\alpha x z
$$




$$
\begin{aligned}
& \frac{d y}{d t}=s y\left(1-\frac{y}{L}\right)+\sigma_{1} x-\sigma_{2} y \\
& \frac{d z}{d t}=\beta x z-e z-q_{3} z E_{3} .
\end{aligned}
$$

2. Terdapat tiga titik keseimbangan yang diperoleh, yaitu

$$
T_{1}=(0,0,0,), T_{2}=(\bar{x}, \bar{y}, 0,) .
$$

Dengan $\bar{x}>\frac{\left(r-\sigma_{1}\right)(g H+K)}{r}, \bar{y}=\frac{1}{\sigma_{2}}\left[\frac{r x^{2}}{g H+K}-\left(r-\sigma_{1}\right) x\right]$

$T_{3}=\left(x^{*}, y^{*}, z^{*}\right)$.

Dengan $x^{*}=\frac{e+q_{3} E_{3}}{\beta}, y^{*}=\frac{L\left(s-\sigma_{2}\right)+\sqrt{\left(L\left(s-\sigma_{2}\right)\right)^{2}+4 s L \sigma_{1} x^{*}}}{2 s}$

$z^{*}=\frac{1}{\alpha(g H+K)}\left[\left(r-\sigma_{1}\right)(g H+K)-r x^{*}+\frac{\sigma_{2} y^{*}(g H+K)}{x^{*}}\right]$.

3. Titik keseimbangan $T_{3}$ merupakan titik interior merupakan titik yang akan dianalisis kestabilannya karena keadaan jumlah spesies bernilai positif. Hasil simulasi numerik dengan pemanenan dengan memakai nilai parameter diperoleh usaha pemanenan optimal yang memberikan titik keseimbangan interior tersebut yaitu titik dengan $T_{3}=$ $\left(x^{*}, y^{*}, z^{*}\right)$ merupakan stabil asimtotik serta usaha pemanenan dari spesies pemangsa yang memberikan keuntungan maksimal. Dari hasil analisis baik dengan teoritis, maupun dengan numerik dapat disimpulkan bahwa kestabilan titik keseimbangan interior $T_{3}=\left(x^{*}, y^{*}, z^{*}\right)$ ditentukan oleh nilai usaha pemanenan yang diberikan. Juga dari simulasi model dapat disimpulkan bahwa spesies mangsa dan pemangsa tidak akan punah seiring berjalannya waktu dengan usaha pemanenan. Dengan demikian pemangsa yang dieksplotasi dengan usaha pemanenan konstan tetap lestari untuk waktu yang lama serta memberikan keuntungan maksimal.

\section{Daftar Pustaka}

[1] Chakraborty, K., Chakraborty, M., dan Kar, T.K. 2011. Bifurcation and Control of a Bioeconomic Model of a Prey-Predator System with a Time Delay. Nonlinear Analysis: Hybrid Systems. 5: 613-625.

[2] Daga, N., Singh, B., Jain, S., dan Ujjainkar, G. 2014. Stability Analysis of a Prey-Predator Model with a Reserved Area. Advances in Applied Science Research, 5(3): 293-301.

[3] Dubey, B. 2007.A Prey-Predator Model with a Reserved Area. Nonlinear Analysis: Modelling and Control, Vol.12, No.4, 479-494. 
Syamsul Agus, Syamsuddin Toaha, Kasbawati

[4] Foley, N.S., Armstrong, C.W., Kahui, V., Mikkelsen, E., dan Reithe, S. 2011. A Review of Bioeconomic Modelling of Habitat-Fisheries Interactions. International Journal of Ecology Vol 2012. Article ID 861635, 11 pages

[5] Kar, T.K. dan Pahar, U.K. 2007 A Model Prey-Predator Fishery With Marine Reserve. Journal of Fisheries and Aquatic science 2(3): 195-205

[6] Lv, Y., Yuan, R., dan Pei,Y. 2013. A Prey-Predator Model with Harvesting for Fishery Resource with Reserve Area. Applied Mathematical Modelling.37 : 3048-3062.

[7] Prastiwi, L. 2013. Kontrol Optimal Model Bioekonomi Mangsa-Pemangsa dengan Waktu Tunda. Program Pascasarjana ITS.

[8] Zhang, R., Sun, J., dan Yang, H. 2007. Analisis of a Prey Predator Fishery Model with Prey Reserve. Applied Mathematical Sciences. Vol. 1. No. 50, 2481-2492 